\title{
ANALYSIS OF ENVIRONMENTAL PROTECTION EXPENDITURES AND THEIR INFLUENCE ON THE QUALITY OF THE ENVIRONMENT
}

\section{Claudia Sîrbulescu*, Luminița Pîrvulescu, IAsmina Iosim, Tiberiu IANCu, Ana- MARIANA DinCU}

\author{
Banat's University of Agricultural Sciences and Veterinary Medicine "King Michael I of \\ Romania" from Timisoara, \\ Faculty of Management and Rural Tourism, \\ Calea Aradului, no.119, 300645, Timisoara, Romania \\ *Corresponding author: claudiasirbulescu@,usab-tm.ro
}

\begin{abstract}
The environment is an important element in ensuring working and living conditions, but the evolution of industries, especially those polluting branches, have had the effect of deteriorating the quality of the environment. Measures to protect it are becoming increasingly necessary.

Environmental protection must be a priority in all aspects of our work, and we must look for ways to protect the Earth's resources for future generations.

In the article we have presented an analysis of the evolution of environmental protection expenditures. Environmental protection expenditure is the economic measure of the response of the community to solve environmental problems at a given time.

Companies in the national economy reserve funds for environmental protection activities. The amounts allocated differ from one sector of activity to another, but also from one year to another.

The field of environmental protection is considered very important for the population. Expenditures on environmental protection involve, on the one hand, expenditures for carrying out environmental surveillance and protection activities, and, on the other hand, expenditures related to the prevention or repair of damages caused to it.

It is found that the costs involved in environmental protection are greatly reduced when its degradation is prevented, compared to the situation in which it needs to be repaired.

The environment must be protected not only by the requirements of European directives but also by a national program to eliminate pollution.

Regarding the expenditures for environmental protection in Romania, the situation was much improved by increasing the amounts available, as a result of economic growth, but also of budget revenues.
\end{abstract}

Keywords: environment, resources, environmental protection.

\section{INTRODUCTION}

In this article, we aim to focus on environmental spending because the people is interested in issues related to both air and water pollution and the fact that the population is increasingly affected by global warming.

The environment and natural resources are the main elements of the functioning of the economic system. These are the "natural foundation of economic activities", which can accentuate or limit the development of society. (TOBULTOC, 2003)

In a document of the Council of the European Union "the environment means water, air and soil in their interaction, as well as the relationship between them and any other living organism" (art. 2, Council Directive of 27 June 1967).

According to the Romanian Constitution, the term environment is not expressly defined, but from art. 135 results that "the environment is the favorable framework for creating the necessary conditions for increasing the quality of life." (ROMANIAN CONSTITUTION) 
Pollution, by inoculating matter or energy in the environment with destructive or harmful effects, affects ecosystems, reduces biological resources and affects human health (MunTEANU et al., 2011)

Environmental issues are of a particular complexity, the causes being interdependent, which implies the need for actions at all levels: local, national and regional, each having a role in increasing responsibility for environmental protection (COMǍNESCU, 2010).

The environmental protection is in the focus of international institutions, which monitor the activity carried out by all countries in this field. It is noted that through the actions taken, Romania registers some positive results, being ahead of some European countries, but also from other continents. (MARINESCU et al., 2018)

Environmental protection considers several actions: rational management of resources, avoidance of imbalances by nature conservation, avoidance of environmental pollution, as well as its ecological reconstruction. Environmental protection measures include "establishing an obligation, establishing special conditions and stipulating prohibitions on the rational use of natural resources, preventing and combating environmental pollution and the harmful effects of natural phenomena on its components". These measures aim to maintain the ecological balance in order to ensure better living and working conditions for future generations. (KAPOSTA, 2009; VIŞAN et al., 2000)

The quality of the environment is the essential, inseparable element from the quality of life. The quality of the environment also positively affects economic growth, because it acts favorably on the primary factor of production - man, by maintaining health and reducing health care costs, but also contributing to ensuring and activating natural factors of production - the land and its full range of wealth. (GHEREŞ, 2007)

Environmental protection expenditure is an economic measure of society's response to addressing the issues involved in the state of the environment at a given stage. Included are the expenses for carrying out the activities of surveillance and protection of the environment and the expenses related to the prevention or repair of the damages brought to it. (FRĂSINEANU and BĂLOIU, 2007)

The motivation for choosing this theme was determined by the fact that a clean environment is the key element in ensuring working and living conditions.

The objective of the paper is to analyze the expenditure for environmental protection as it allows the evaluation of the effort made to prevent, reduce and eliminate pollution, considering that environmental protection contributes to stimulating the increase of quality of life.

\section{MATERIALS AND METHODS}

In order to carry out the work, we used, in addition to the specialized literature and include books, specialized works (FRĂSINEANU and BĂLOIU, 2007; GHEREŞ, 2007; KAPOSTA, 2009; MUNTEANU et al., 2011; VIŞAN et al., 2000) and data on environmental protection expenses extracted from the INS Statistical Yearbooks (INS, 2015-2020), on the basis of which we made our own interpretations, as presented in a number of tables and figures.

The method of scientific research used was the comparative analysis of expenditures by main categories of producers, in the period 2015-2020.

Environmental protection expenditures represent environmental financing flows and include payments for economic activities aimed at producing specific services to prevent, reduce or combat environmental damage. It is grouped into: current investments and expenditures that include internal current expenditures ("wages and social contributions, consumption of raw materials, fuels, energy, water and other auxiliary materials, expenditures for research and development, training, information, environmental 
management") and external current expenses (expenses for environmental protection services purchased from third parties and for environmental taxes paid) (INS, 2020)

\section{RESULTS}

The expenditures for environmental protection in Romania were of approximately 16 billion lei, in 2019, representing 1.5 percentage points of GDP, according to the data provided by INS.

The expenses regarding the environmental protection were analyzed following the main categories of producers, presented in Table 1, so for the period 2015-2019 we would find the following: the expenses for environmental protection at non-specialized producers reached a maximum in 2015 (9,262,709 thousand lei); that the expenses for environmental protection of specialized producers decreased in 2016 (4,844,684 thousand lei), following an upward trend in the following years.

In the public administration sector, the expenditures doubled in 2019 in comparison with 2015.

Table 1. Evolution by sectors of activity of environmental protection expenditures

\begin{tabular}{|l|r|r|r|r|r|}
\hline \multicolumn{5}{|c|}{ - RON thousand current prices } \\
\hline Activity sectors & $\mathbf{2 0 1 5}$ & $\mathbf{2 0 1 6}$ & $\mathbf{2 0 1 7}$ & $\mathbf{2 0 1 8}$ & $\mathbf{2 0 1 9}$ \\
\hline Unspecialized producers & $\mathbf{9 , 2 6 2 , 7 0 9}$ & $\mathbf{4 , 8 4 4 , 6 8 4}$ & $\mathbf{5 , 2 5 3 , 3 0 4}$ & $\mathbf{6 , 9 5 3 , 3 2 2}$ & $\mathbf{6 , 2 1 5 , 0 5 3}$ \\
\hline $\begin{array}{l}\text { Forestry, logging and related service } \\
\text { activities }\end{array}$ & 46,675 & 269,955 & 246,967 & 270,720 & 36,003 \\
\hline Mining and quarrying & & & \\
\hline Manufacturing & 553,873 & 474,329 & 620,704 & $1,569,569$ & $1,202,105$ \\
\hline $\begin{array}{l}\text { Electric and thermal energy, gas and } \\
\text { hot water production and supply }\end{array}$ & $2,612,875$ & $1,202,476$ & $1,582,996$ & $2,195,952$ & $1,860,235$ \\
\hline $\begin{array}{l}\text { Water collection, treatment and } \\
\text { supply }\end{array}$ & $2,767,395$ & $1,257,777$ & $1,013,776$ & $1,115,525$ & 996,684 \\
\hline Construction & 117,977 & 146,059 & 135,482 & 144,852 & 217,413 \\
\hline Transport & 223,236 & 224,986 & 275,056 & 259,281 & 284,414 \\
\hline Other activities & - & & 21,012 & 29,464 & 93,102 \\
\hline Specialized producers & $\mathbf{6 , 2 2 9 , 3 8 2}$ & $\mathbf{5 , 1 3 8 , 7 5 8}$ & $\mathbf{6 , 2 0 3 , 9 1 9}$ & $\mathbf{6 , 7 3 2 , 4 3 0}$ & $\mathbf{7 , 1 5 7 , 5 0 7}$ \\
\hline General government & $\mathbf{4 , 5 0 7 , 5 3 4}$ & $\mathbf{5 , 5 2 0 , 7 0 0}$ & $\mathbf{4 , 3 1 0 , 4 0 3}$ & $\mathbf{7 , 1 8 0 , 5 0 0}$ & $\mathbf{9 , 2 0 7 , 4 0 0}$ \\
\hline
\end{tabular}

Sources: $\underline{w w w . i n s s e . r o}$ 
Table 2. Expenditures on environmental protection by categories of producers and expenditures

- RON thousand current prices-

\begin{tabular}{|c|c|c|c|c|}
\hline Types of producers & Investments & $\begin{array}{c}\text { Current } \\
\text { expenditure } \\
\text { internal }\end{array}$ & $\begin{array}{c}\text { Current } \\
\text { expenditure } \\
\text { external }\end{array}$ & Transfers \\
\hline \multicolumn{5}{|c|}{2015} \\
\hline Unspecialized producers & $4,828,570$ & $2,706,216$ & $1,727,923$ & - \\
\hline Specialized producers & 775,695 & $4,458,577$ & 995,110 & - \\
\hline General government & $1,140,763$ & $1,530,528$ & $1,687,356$ & \\
\hline \multicolumn{5}{|c|}{2016} \\
\hline Unspecialized producers & $1,233,658$ & $1,507,782$ & $2,103,244$ & - \\
\hline Specialized producers & 285,600 & $3,801,206$ & $1,051,952$ & - \\
\hline General government & $1,485,200$ & 709,018 & $1,166,683$ & $2,159,800$ \\
\hline \multicolumn{5}{|c|}{2017} \\
\hline Unspecialized producers & 887,667 & $1,671,874$ & $2,693,763$ & - \\
\hline Specialized producers & 266,043 & $4,449,551$ & $1,488,325$ & - \\
\hline General government & $1,152,299$ & $1,073,011$ & $1,272,689$ & 812,404 \\
\hline \multicolumn{5}{|c|}{2018} \\
\hline Unspecialized producers & $1,657,409$ & $1,947,580$ & $3,348,333$ & - \\
\hline Specialized producers & 400,913 & $4,833,490$ & $1,498,027$ & - \\
\hline General government & $1,434,900$ & $1,147,962$ & $1,356,038$ & $3,241,600.00$ \\
\hline \multicolumn{5}{|c|}{2019} \\
\hline Unspecialized producers & $1,174,478$ & $1,802,715$ & $3,237,860$ & - \\
\hline Specialized producers & 446,773 & $4,925,477$ & $1,785,257$ & - \\
\hline General government & $1,951,400$ & $1,436,859$ & $1,631,941$ & $4,187,200$ \\
\hline
\end{tabular}

Sources: $\underline{w w w . i n s s e . r o}$

The structure of expenditures made by non-specialized producers in 2019 is as follows: in the field "production and supply of electricity and heat, gas and hot water" were recorded $29.93 \%$ of expenditures, while in the sector "manufacturing industry" $24.49 \%$ were achieved, while the "extractive industry" sector spent $19.34 \%$ of the expenses of nonspecialized producers.

There is also a doubling of construction expenditures in the analyzed period.

At national level, the investment structure in 2019 was as follows: public administration investments represented $54.6 \%$ of total investments for environmental protection, investments of non-specialized producers $32.9 \%$ and investments of specialized producers $12.5 \%$ of the total (Table 2 and Figure 1).

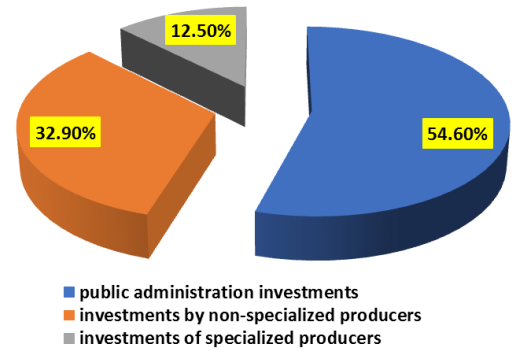

Figure. 1. Investments in environmental protection, by categories of producers, in 2019

Sources: $\underline{w w w . i n s s e . r o}$ 


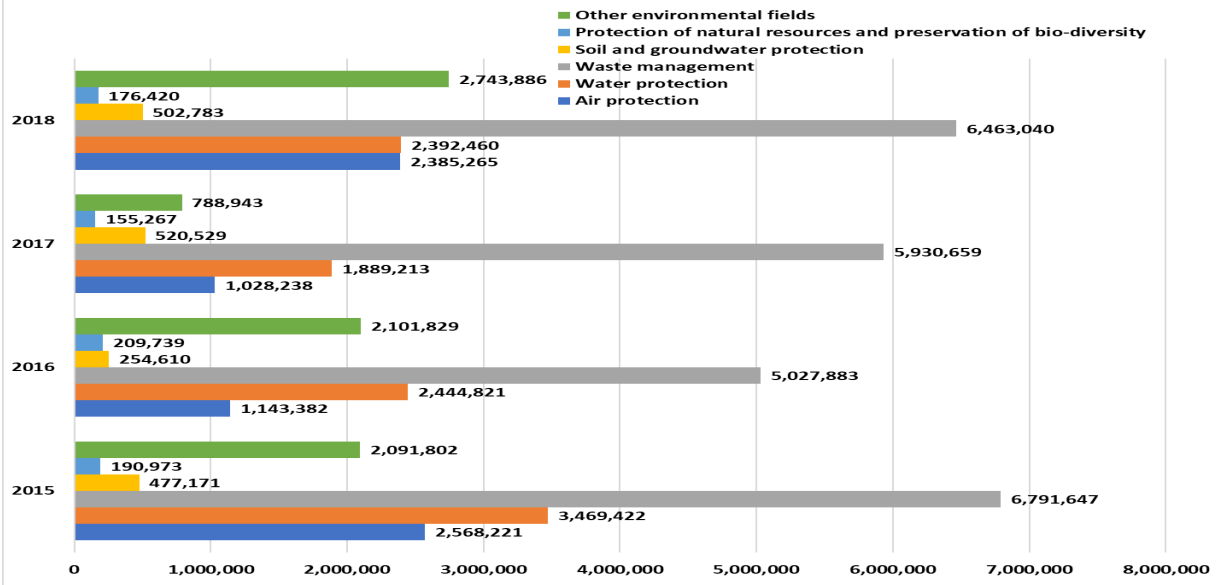

Figure 2. Structure of expenditures for environmental protection by environmental domains (RON thousand current prices)

Sources: www.insse.ro

By environmental areas (Figure 2) in 2019, the highest expenditures were registered in waste management, $42 \%$ of the total expenditures on environmental protection made at national level, then those for air and climate protection $19.8 \%$ and those for wastewater management (19.7\%). Actions on environmental protection that are eligible for support under the National Framework include: "Air Protection, Wastewater Management, Waste Management, Soil and Groundwater Protection, Natural Resource Protection and Biodiversity Conservation, Other Environmental Areas".

In Table 3 we analyzed the evolution of environmental protection expenditures for nonspecialized producers, by environmental fields, in the period 2015-2019 and we highlighted the following aspects: wastewater management expenditures decreased during the analyzed period approximately 2.5 times in 2019 . The other categories of expenditures had an oscillating evolution: expenditures on waste management decreased in 2016, increased in the next two years, and in 2019 decreased, expenditures on soil and groundwater protection increased in year 2019, and expenditures with other environmental fields, were reduced 5.3 times in 2019 compared to 2015.

Table 3. Expenditures on environmental protection of non-specialized producers, by environmental fields

\begin{tabular}{|c|c|c|c|c|c|}
\hline \multicolumn{6}{|c|}{ - RON thousand current price } \\
\hline \begin{tabular}{|l} 
Environmental fields \\
Years \\
\end{tabular} & 2015 & 2016 & 2017 & 2018 & 2019 \\
\hline Air protection & $2,329,749$ & 425,516 & 332,750 & $1,083,325$ & 708,188 \\
\hline Water protection & $2,522,504$ & $1,251,416$ & 997,224 & $1,056,911$ & $1,076,796$ \\
\hline Waste management & 458,245 & 238,498 & 303,709 & 404,714 & 356,330 \\
\hline Soil and groundwater protection & 416,369 & 233,235 & 409,870 & 408,108 & 495,963 \\
\hline $\begin{array}{l}\text { Protection of natural resources and } \\
\text { preservation of biodiversity }\end{array}$ & 79,984 & 183,471 & 152,720 & 172,992 & 15,597 \\
\hline Other environmental fields & $1,727,935$ & 409,304 & 363,268 & 478,939 & 324,319 \\
\hline
\end{tabular}

Sources: www.insse.ro

Table 4 shows the expenditures for environmental protection of specialized producers for the period 2015-2019 and we found the following: expenditures registered a sinuous evolution with increases followed by reductions. Expenditures on waste management decreased in $2016(3,852,293$ thousand lei), then followed increases from one year to another until 2019 (from 4,788,232 thousand lei in 2015 to 4,891,837 lei in 2019), 
expenditures on wastewater management doubled from 2015 to 2019, and expenditures for other environmental areas decreased 29.55 times.

Table 4. Environmental protection costs of specialized producers, by environmental fields

\begin{tabular}{|l|r|r|r|r|r|}
\hline Environmental fields & \multicolumn{5}{|c|}{ - RON thousand current prices- } \\
\hline Aears & $\mathbf{2 0 1 5}$ & $\mathbf{2 0 1 6}$ & $\mathbf{2 0 1 7}$ & $\mathbf{2 0 1 8}$ & $\mathbf{2 0 1 9}$ \\
\hline Water protection & 17,482 & 108,310 & 12,320 & 130,170 & \multicolumn{1}{c|}{43.232} \\
\hline Waste management & 129,453 & 61,849 & 76,041 & 77,580 & 278,926 \\
\hline Soil and groundwater protection & $4,788,232$ & $3,852,293$ & $4,544,257$ & $5,010,188$ & $4,891,837$ \\
\hline $\begin{array}{l}\text { Protection of natural resources and } \\
\text { preservation of biodiversity }\end{array}$ & 20,795 & 8,709 & 51,995 & 3,941 & 146,146 \\
\hline Other environmental fields & 118 & 390 & 1,679 & 2,143 & 2,695 \\
\hline
\end{tabular}

Sources: www.insse.ro

Table 5. Environmental expenditure of the public administration on environmental areas

\begin{tabular}{|l|r|r|r|r|r|}
\hline Environmental fields & \multicolumn{5}{|c|}{ - RON thousand current prices- } \\
\hline Air protection & $\mathbf{2 0 1 5}$ & $\mathbf{2 0 1 6}$ & $\mathbf{2 0 1 7}$ & $\mathbf{2 0 1 8}$ & $\mathbf{2 0 1 9}$ \\
\hline Water protection & 220,990 & 609,556 & 683,168 & $1,171,770$ & $2,405,022$ \\
\hline Waste management & 817,465 & $1,131,556$ & 815,948 & $1,257,969$ & $1,774,562$ \\
\hline Soil and groundwater protection & $1,545,170$ & 937,092 & $1,082,693$ & $1,048,138$ & $1,441,534$ \\
\hline $\begin{array}{l}\text { Protection of natural resources and } \\
\text { preservation of biodiversity }\end{array}$ & 40,007 & 12,666 & 58,664 & 90,734 & 608,175 \\
\hline Other environmental fields & 110,871 & 25,878 & 868 & 1,285 & 1,458 \\
\hline
\end{tabular}

Sources: www.insse.ro

The expenses of the public administration presented in Table 5, increased between 20152019: the expenses with air protection increased significantly, from 220,990 thousand lei in 2015 to 2,405,022 thousand lei in 2019, 10.8 times; with other environmental areas have increased 15.69 times, spending on natural resources protection and biodiversity conservation decreased considerably 76 times in 2019, which has implications for quality of life because biodiversity is the primary condition of human civilization and ensures the support system of life and the development of socio-economic systems.

For the coming years, efforts to improve environmental protection measures must become a key concern for all parties involved in this field. In the vision of the Department for Environmental Protection, and of some European specialists, and according to some estimates, in the next 20 years, in order to keep the ecological balances as close as possible to the environmental standards, financial efforts of over 20 billion euros will have to be made so as to lead to ensuring a real protection on the economic evolution in Romania.

\section{DISCUSSION}

The results highlight the fact that man by building factories and plants, developing cities and transport, deforestation for wood use and growing agricultural areas, carelessly throwing large amounts of toxic waste into the water and air, has damaged the natural balance in the environment. It is thus necessary to ensure a much better ordered and protected evolution in the future, so that the quality of the environment is protected.

Pollution and environmental protection are among the most important problems facing Romania and humanity in general. 
Global changes related to the quality of the environment involve finding solutions to maintain the ecological balance of the planet, in conditions of sustainable development.

We found that for the period 2015-2019, the environmental protection expenditures of nonspecialized producers decreased, due to the increase in environmental protection expenditures of specialized producers, respectively those in the public administration sector.

In conclusion, for the next period it is necessary to further monitor these expenditures and especially the environmental protection measures must be intensified and emphasized, and in the polluting branches their evolution must be sufficiently protected on one hand, and on the other part must be ensured the mitigation of the effects of pollutants.

\section{REFERENCES}

Comănescu, M. (2010): Creșterea responsabilității față de mediu. Economie teoretică și aplicată, XVII, 5(546): 39-52

Frăsineanu, I.; Băloiu, L. (2007): Economia și protecția mediului înconjurător. Editura ASE, București

Ghereş, M. (2007): Economia și protecția mediului. Editura Risoprint, Cluj - Napoca

Marinescu, R. T.; Dumitru, D.; Stoica, R. (2018): Analiza situației mediului înconjurător și influenţa acestuia asupra evoluției economice. Revista Română de Statistică Supliment, 10: 52-63.

Kaposta, I. (2009): Ecologie și protecția mediului. Editura Politehnica, Timișoara

Munteanu, C.; Dumitraşcu, M.; Iliuţă, R. A. (2011): Ecologie și protecția calităţii mediului. Editura Balneară, București

Tobultoc, V. (2003): Mediu - tehnologie - dezvoltare, Tribuna Economică 43: 64-67.

Vişan, S.; Angelescu, A.; Alpopi, C. (2000): Mediul înconjurător, poluare și protecție. Editura Economica, București

Constituția României (2003): Drepturile, libertăţile și îndatoririle fundamentale art.35 „Dreptul la un mediu sănătos”, cap. II, www.constitutia.ro

Institutul National De Statistica (2015-2020): Anuarul Statistic al României, www.insse.ro 